\title{
Modelling forest loss and other land use change dynamics in Ashanti Region of Ghana
}

\author{
Addo Koranteng ${ }^{1} \bowtie$, Tomasz Zawila-Niedzwiecki ${ }^{2}$ \\ ${ }^{1}$ Kumasi Polytechnic, School of Graduate Studies, Research and Innovation, P.O. BOX 854, Kumasi, Ghana, \\ e-mail:dr.adokay@gmail.com \\ ${ }^{2}$ Directorate General of the State Forests, Grójecka 127, 02-124 Warszawa, Poland
}

\section{Abstract}

Forest losses amid land use dynamics have become issues of outermost concern in the light of climate change phenomenon which has captivated the world's attention. It is imperative to monitor land use change and to forecast forms of future land use change on a temporal and spatial basis. The main thrust of this study is to assess land use change in the lower half of the Ashanti Region of Ghana within a 40 year period. The analysis of land use change uses a combination method in Remote Sensing (RS) and Geographic Information System (GIS). Cellular Automata and Markov Chain (Cellular Automata-Markov) are utilized to predict for land use land cover (LULC) change for 2020 and 2030. The processes used include: (i) a data pre-processing (geometric corrections, radiometric corrections, subset creation and image enhancement) of epoch Landsat images acquired in 1990, 2000, and Disaster Monitoring Constellation (DMC) 2010; (ii) classification of multispectral imagery (iii) Change detection mapping (iv) using Cellular Automata-Markov to generate land use change in the next 20 years. The results illustrate that in years 2020 to 2030 in the foreseeable future, there will an upsurge in built up areas, while a decline in agricultural land use is envisaged. Agricultural land use would still be the dominant land use type. Forests would be drastically reduced from close to $50 \%$ in 1990 to just fewer than $10 \%$ in 2030 . Land use decision making must be very circumspect, especially in an era where Ghana has opted to take advantage of REDD+. Studies such as this provide vital pieces of information which may be used to monitor, direct and influence land use change to a more beneficial and sustainable manner.

\section{KeY WORDS}

Cellular Automata-Markov, forest modelling, GIS, land use change, remote sensing

\section{INTRODUCTION}

Deforestation in Ghana has always been a critical issue since the 1930s as a result of the various dynamic forces causing it (Benneh and Agyepong 1990). The colonial forest policies of the past, forcefully appropriated forest lands from individual land owners and families for vari- ous reasons. The affected individuals and communities resorted to exploiting the forest cover indiscriminately, regardless of the negative effects on forest cover (Agbosu 1983). During the 1960s and 1970s, deforestation was exacerbated as a result of cultivation of cocoa as an export commodity (Dei 1992). Timber became the main driver of deforestation in 1981 to 1985 . At this time, 
timber was the third largest export commodity contributing between 5\% and 7\% of Ghana's Gross Domestic Product (GDP), (IIED 1987). The country's annual deforestation rate then was estimated at 1.3\%. From 1990 to 2005 a quarter of Ghana's total forest cover was lost (Boafo 2013). The cumulative anthropogenic causes of deforestation contributed to a reduction of Ghana's forest cover from 8.2 million hectares to an estimated 0.836 million hectares of forest in 2000, indicating an annual deforestation rate of $2.8 \%$ (EPA 2004). If this rate is not curtailed, a complete disappearance of forests in 25 years will result (Boafo 2013).

Anthropogenic activities and actions are the proximate causes of deforestation and forest degradation. Agricultural activities are deemed to be responsible for around $80 \%$ of deforestation worldwide. In most parts of Africa, fuel wood collection for firewood and charcoal production, and, to a lesser extent, livestock grazing in forests are the most significant drivers of forest degradation. Underlying or indirect causes are complex connections of social, economic, political, cultural and technological processes that affect the direct drivers to cause deforestation or forest degradation (Abay 2014; Aragão et al. 2014; Bele et al. 2014; Jabbour and Hunsberger 2014; Kalema et al. 2014; Medrilzam et al. 2013; Monson 2013). They act at multiple scales: international (markets, commodity prices), national (population growth, domestic markets, national policies, governance) and local circumstances (subsistence, poverty).

The intricacy of forecasting Land-Use, Land-Use Cover, and Forestry (LULUCF) has resulted in wideranging approaches being formulated. These models vary based on purposes, methodologies, geographic areas of the analysis, assumptions and both the source and type of data used. These models include Geographic/ Land-Cover,Economic/land-use change and Model Linkages and Integration (Michetti and Zampieri 2014).

Geographic/land-cover models have been enhanced by the quick development of remote sensing and Geographic Information Systems (GIS). Spatial measurement and geographical/physical features of the land problem are dominant to this category of analysis. ACCELERATE (Rounsevell et al. 2003), ELPEN-System (Wright et al. 1999), CLUE (Veldkamp and Fresco 1996) and Dyna-CLUE (Verburg and Overmars 2009), EFISCEN (Schelhaas et al. 2007), SALU (Stephenne and Lambin 2001; 2004), MedAction (Van Delden et al.
2007), KLUM (Ronneberg et al. 2005) and many others are geographic models which have been used for landcover analysis all over the world.

Markov chain model was specifically chosen for this study because it is relatively simple to use and gives satisfactory results. Huang et al. (2015) used Markov based cellular automata (CA) model for simulating and forecasting urban land use change Land use change in Wuhan city (China) by means of satellite images from 1999 to 2005 . Razavi (2014), in this study, the changes in land use and land cover in Kermanshah City, Iran from 1987 through 2000 to 2006 was perused. Multi-temporal Landsat satellite images, site information and Markov Chain Model were used. Mishra et al. (2014), in Muzaffarpur-Bihar (India) Landsat satellite images for 1988 and 2010 were used for change prediction and forecast map for years 2025 and 2035. IDRISI, Land Change Modeler (LCM) was employed to evaluate the land use and land cover modifications between various classes for 1988-2008.

The main thrust of this study is to appraise land use and forecast future land use changes in lower half Ashanti Region in Ghana.

\section{Methodology}

\section{Study area}

Ashanti region lies approximately at the center of Ghana (fig. 1). It covers an area of $24,390 \mathrm{~km}^{2}$ representing $10.2 \%$ of the land area of Ghana. Ashanti has abundant food. The Region is endowed with large deposits of gold and bauxite. Other mineral deposits of economic value found in the Region include manganese, iron, silica, clay and limestone. Traces of copper, platinum, lithium, tin arsenic and mica are also found (www.ghanaweb.com). It is the most populous region in Ghana. According to the 2010 Population Census, the Region recorded a total of 4,780,380 representing $19.4 \%$ of national total of $24,658,823$ (GSS 2013).

The study area (Southern part of Ashanti Region) lies in the deciduous forest zone between latitudes 651054.0 and 663924.0S, and stretches between longitudes 679950.0 to $667110.0 \mathrm{~W}$. The area selected for this study includes 12 districts which are Atwima Mponua, Amansie West, Bosomtwe-Kwanwoma, Amansie Central, Amansie East, Asante Akin South, Amansie West, Amansie Central, Adansi North, Adansi South and Obuasi Municipal where the Anglogold Obuasi mine is located. 


\section{DE GRUYTER}

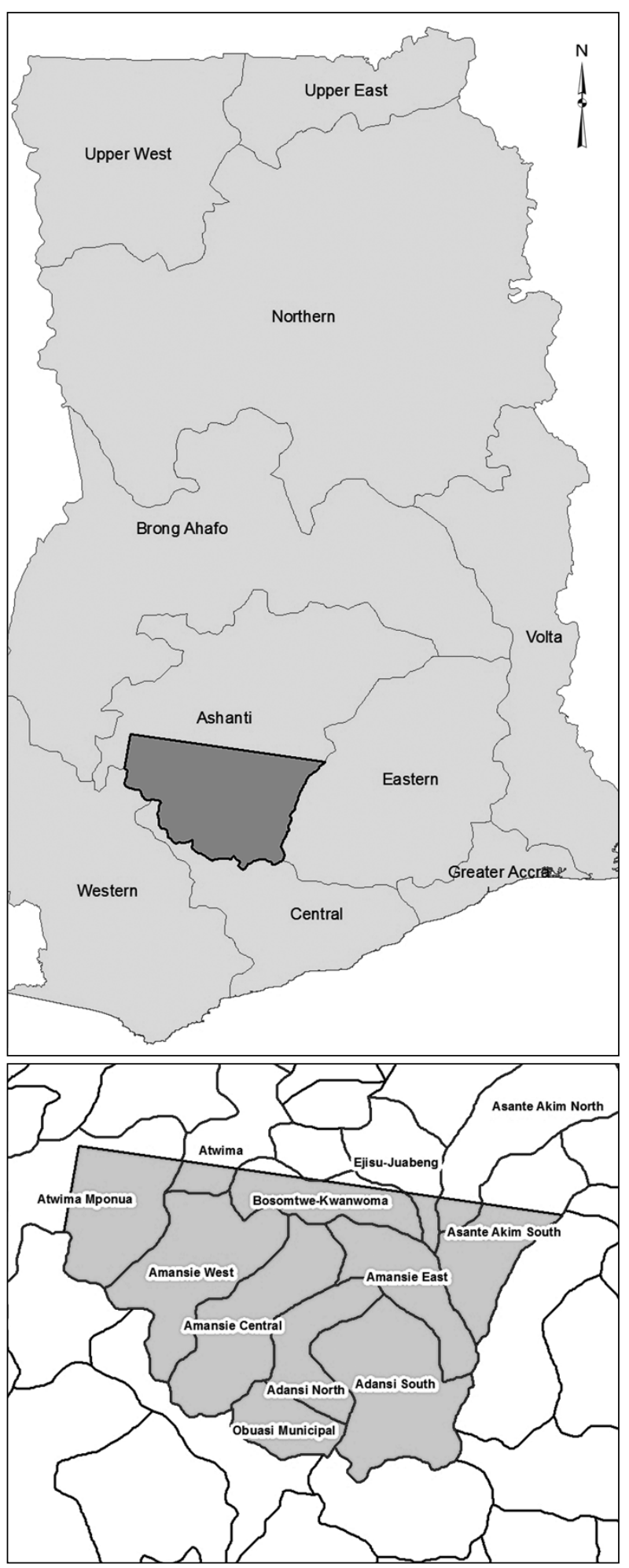

Figure 1. Map of Ghana showing AOI
A meteorite lake called Bosumtwi, is located within an ancient meteorite impact crater is located here. This natural lake provides livelihood in the form of fishing industry to the surrounding communities and serves as a popular tourist attraction destination to both local and foreign tourist (Jones et al. 1981).

\section{Material}

Satellite images and reference data employed for this study were obtained from the Forestry Commission of Ghana, under the Forest Preservation Program (FPP-Ghana) 2011/2012.

Table 1. Remote sensing images for the study

\begin{tabular}{|c|c|c|c|c|}
\hline $\begin{array}{c}\text { Area of } \\
\text { interest } \\
\text { (AOI) }\end{array}$ & Data & $\begin{array}{c}\text { Date of } \\
\text { acquisition }\end{array}$ & $\begin{array}{c}\text { Reso- } \\
\text { lution }\end{array}$ & $\begin{array}{c}\text { Path and } \\
\text { rows }\end{array}$ \\
\hline \multirow{3}{*}{$\begin{array}{l}\text { Ashanti } \\
\text { Region }\end{array}$} & Landsat TM & 29.12 .1986 & 28.50 & $\begin{array}{c}\text { WRS-194, } \\
\text { WRS056 }\end{array}$ \\
\cline { 2 - 5 } & Landsat ETM+ & 2.01 .2002 & 28.50 & $\begin{array}{c}\text { WRS-194, } \\
\text { WRS056 }\end{array}$ \\
\cline { 2 - 5 } & DMC & 19.01 .2011 & 22.00 & \\
\hline
\end{tabular}

Table 2. Reference data for study

\begin{tabular}{|l|c|c|l|}
\hline \multicolumn{1}{|c|}{$\begin{array}{c}\text { Reference } \\
\text { data }\end{array}$} & $\begin{array}{c}\text { Acquisition } \\
\text { date }\end{array}$ & Scale & \multicolumn{1}{|c|}{ Sources } \\
\hline $\begin{array}{l}\text { Topographical } \\
\text { map }\end{array}$ & 2008 & $1: 50,000$ & $\begin{array}{l}\text { Survey Depart- } \\
\text { ment, Ghana }\end{array}$ \\
\hline $\begin{array}{l}\text { Aerial } \\
\text { photograph }\end{array}$ & 2004 & $1: 10,000$ & $\begin{array}{l}\text { Survey Depart- } \\
\text { ment, Ghana }\end{array}$ \\
\hline Land cover map & 2002 & $\begin{array}{l}\text { Forestry Depart- } \\
\text { ment, Ghana }\end{array}$ \\
\hline $\begin{array}{l}\text { Digitised topo- } \\
\text { graphical map }\end{array}$ & 2002 & $1: 50,000$ & $\begin{array}{l}\text { Geomatic Eng. } \\
\text { Dept., KNUST }\end{array}$ \\
\hline $\begin{array}{l}\text { FPP ground } \\
\text { truthing and } \\
\text { verification data }\end{array}$ & 2012 & $\begin{array}{l}\text { Forestry } \\
\text { Department } \\
\text { (FPP-Ghana), } \\
\text { Ghana }\end{array}$ \\
\hline
\end{tabular}

\section{Image processing}

The study focused on the forest and land use change for the epoch periods 1990, 2000 and 2010 spanning twenty (20) years. The time series of ten years (10) apart from 1990 to 2000 and then 2000-2010 were under consideration. For the following the epoch scenes were chosen as follows. 
Table 3. Epoch scenes of the remote sensing data

\begin{tabular}{|c|c|c|c|}
\hline AOI & Epoch 1990 & Epoch 2000 & Epoch 2010 \\
\hline $\begin{array}{l}\text { Ashanti } \\
\text { (AOI-1) }\end{array}$ & Landsat TM & Landsat ETM+ & DMC 2011 \\
\hline
\end{tabular}

The selection of Software used in this study centered on the image processing procedures and the forecast of impending land use/cover change. ERDAS Imagine 9.1 was used to perform image processing which included the following processes: pre-processing, image classification, accuracy assessment, and production of a change map. Idrisi 17.0 Selva Edition was used to handle the prognosis part of the study. ARCGIS 10.0 was used to produce the output maps.

Pre-processing involved the following processes; geometric corrections, radiometric corrections, subset creation and image enhancement.

Geometric CORRECTIONS. The individual bands of each of the two images (Landsat TM and Landsat $\mathrm{ETM}+$ ) were combined into single image using the Layer Stack tool in the Utilities toolbar of ERDAS Imagine 9.1. Bands 1, 2, 3, 4, 5 and 7 were stacked together. Band 6 which measures thermal reflectance was omitted because of its different spatial resolution of $120 \mathrm{~m}$ and moreover the study was not measuring heat reflectance. The resultant stacked images which were in the global coordinate system, UTM WGS 84 were re-projected onto the Ghana datum, War Office which is based on Traverse Mercator Projection.

All the images (Landsat TM, Landsat ETM+ and DMC) were re-sampled to $30 \times 30$ meter pixel resolution to make accurate analysis of the datasets and comparability possible using Reproject in the Utilities toolbar of ERDAS Imagine 9.1.

RADiOMETRIC CORRECTIONS. Datasets were already corrected to some extent; but the 1986TM, and 2002ETM+ images were quite hazy and therefore corrected for haze using the haze reduction module in Erdas Imagine 9.1.

Creating subsets (AOIs). The AOI was delineated from the whole individual epoch images for the respective epoch years and scenes. The subset tool in the Utilities in Erdas imagines 9.1 was used for this process via the area of interest (AOI) tool.

IMAGE ENHANCEMENT. The individual subset (delineated) images were enhancement to improve their visual interpretation which is vital during image classification. Histogram Equalization was used. This method is premised on assigning image values to the display levels on the basis of their frequency of occurrence (Lillesand and Kiefer 2008).

\section{Land use classes}

For the study purposes forest cover derived from satellite imagery and its change over time are the most important factors. After analyzing satellite data, literature on the subject and author's experience from the area it was decided to use not only information on forest cover but also land use classes to characterize extend and directions of forest cover change. Thus following land use/cover classes were distinguished:

FOREST. This contains all land with woody vegetation consistent with measurements used to outline Forests in the national greenhouse gas inventory. Additionally all vegetation structure that currently fall below, but in situ could potentially reach the Ghana's threshold values.

Minimum Mapping Unit (MMU) is 1.0 ha; Minimum crown cover is $15 \%$; Potential to reach minimum height at maturity (in situ) as 5 meter.

Agriculture. This indicate cropped land, including rice fields, and plantation where the vegetation structure falls below the thresholds used for the Forest Land category. Land where over $50 \%$ of any defined area is used for agriculture, this may be currently cropped or in fallow and may include areas for grazing of livestock.

BuiLT-UPS. These portray all developed land, including social utilities such as transportation infrastructure (roads and highways), built up areas, bare grounds and human settlements of any size.

WATER. These include lands that are covered or saturated by water for all or part of the year (for example peatlands). It also includes reservoirs and natural rivers and lakes.

\section{Image classification}

This study is premised on the application of post-classification change detection to detect forest and other land changes that have taken place. This technique is reliant on two thematic maps of different dates to detect changes; Image Classification was undertaken to extract thematic information from the images.

With assistance from the reference data in section 3.1 and the personal knowledge about the study area, 


\section{DE GRUYTER

fifty (50) training area representing the various land use/ cover classes (Forest-10, Agriculture-20, Built-Ups-15 and Water-5) were digitized on the individual epoch images(1990 TM, $2000 \mathrm{ETM}+$ and 2010 DMC) using the AOI tool and named accordingly in the signature editor of ERDAS imagine 9.1.

After classification, the 50 classes resulting from the 50 training areas were recoded into the broad classes (Forest, Agriculture, Built-Ups and Water) via the Image Interpreter/GIS Analysis/Recode tool in ERDAS Imagine 9.1. The 10 forest classes were recoded as one and given the colour deep green, the 20 Agriculture Classes recoded as Class two and assigned the assigned colour yellow; the 15 Built-Ups classes recoded as three and given colour Maroon and the 5 classes of water recoded as 4 and given colour blue.

Reference data extracted from table 2 were used to perform Accuracy Assessment. The Classifier toolbar of ERDAS Imagine 9.1. In all, one hundred and twenty (120) reference points from the FPP-Ghana field interpretation and verifcation data were used to assess the accuracy of the classified images. This study evaluated the accuracy of the classified images from the matrix generated. Calculation of areas in hectares of the resulting land cover types for each study year was carried out subsequently.

\section{Post-classification change detection method}

The land use/cover classified images converted into maps in ArcGIS and Microsoft Excell used to produce tables of area and percentages. All the three land use/ cover classified images in Erdas format (.img) were exported to raster format (.rst) which is recognized by the Idrisi software.

Cross Tabulation fixed in Idrisi offers information on the occurrences with which each land use/cover classes transitioned from one land use/cover class to the other. Two cross-tabulation tables were generated from thematic maps 1990-2000 and 2000-2010 using the CROSSTAB module in the software.

\section{Prognosis}

Markov Chain analysis and Cellular Automata (CA) in Idrisi were used for the modeling in forecasting land use/cover change in the future. For this study, the two land cover maps 1990 and 2000 were first employed to predict land cover map of 2010. This predicted land cover map was compared with actual land use/cover map of
2010 produced in ERDAS Imagine for validation. After the successful validation, the 1990 and 2000 land cover maps were again used to predict land use/cover map for 2020 and 2030.

\section{Flow chart for the study}

All the processes are summarized in figure 2. This begins with the remote sensing processes. Anthropogenic factors were then juxtaposed to the results and deductions were made.

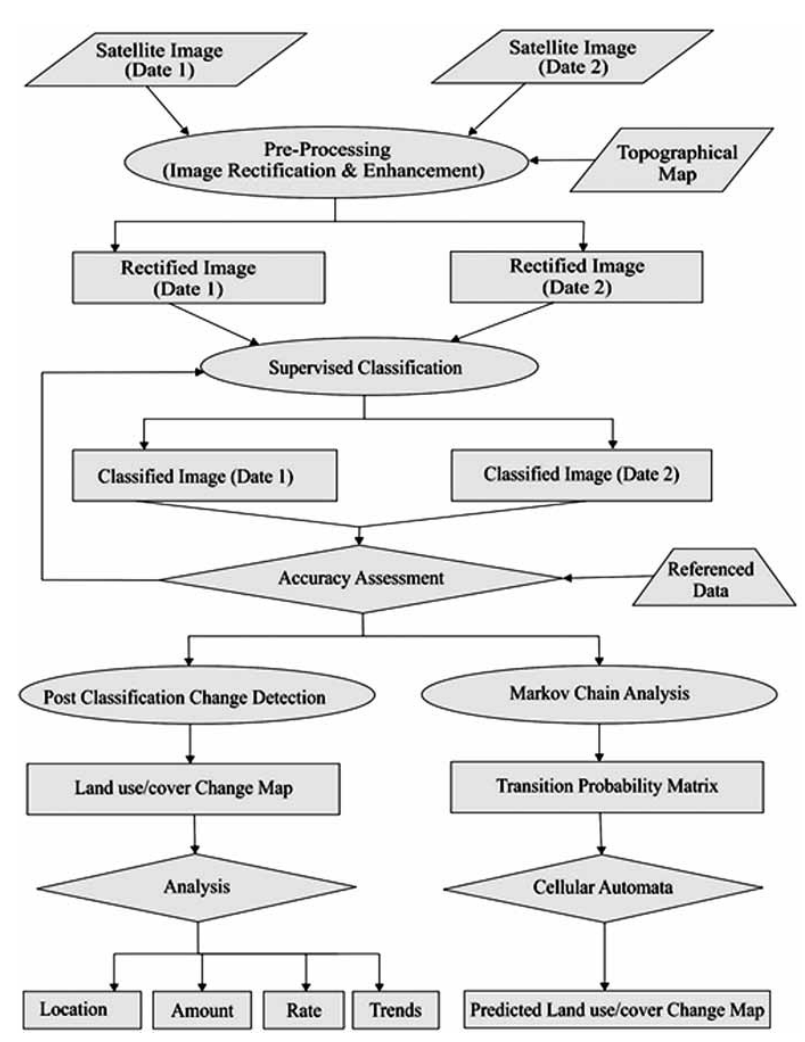

Figure 2. Flow chart showing remote sensing methodology of this study

\section{Results}

Figures 3, 4 and 5 are the extracted images from 1990 epoch Landsat TM, 2000 epoch Landsat ETM+ and DMC 2010 respectively. These are the AOIs for the study in the Ashanti Region. They show the same area that are cloud free and are of interest to this study.

The supervised classification method employed in this study produced three land cover maps from 
the three multi-temporal images - epoch 1990TM, 2000ETM+ and 2010 DMC.

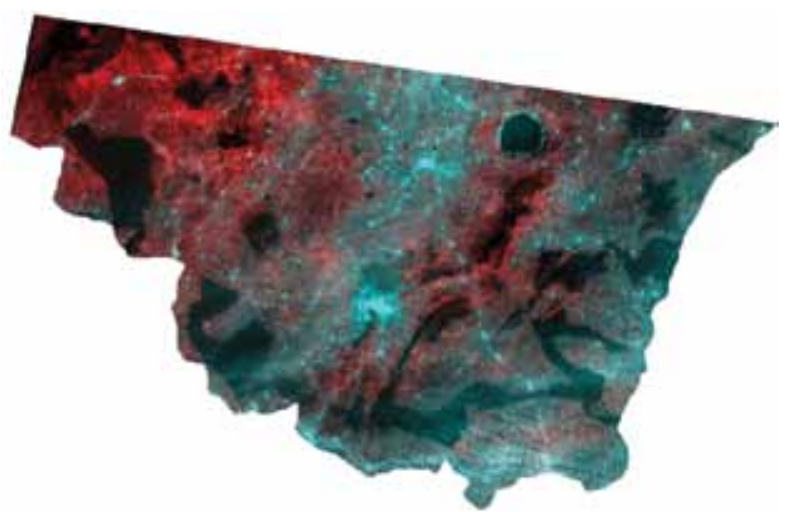

Figure 3. Extracted AOI from 1990 epoch Landsat TM

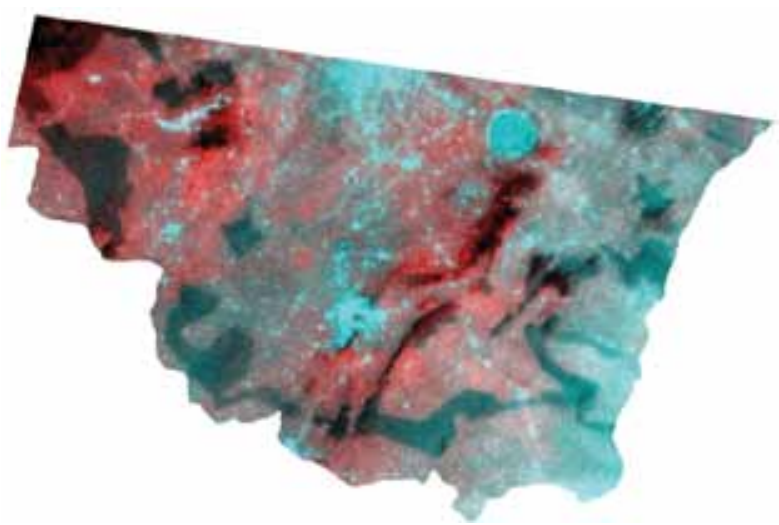

Figure 4. Extracted AOI from 2000 epoch Landsat ETM+

The table 4 shows the extent of the area of the individual land cover categories in hectares (ha) and the percentage they occupied.

The land use/cover map for 1990 epoch (fig. 6) showed Settlements (Built-Ups) areas as very small compared to other LU Class in the map and constitute less than $5 \%$ of the LU. Forest reserves here are relatively undisturbed and constitute a little over $40 \%$ of the LU. Agricultural land forms almost $50 \%$ of the LU. Water share of the LU is about $1 \%$ as lake Bosumtwi and the tailing dam of the AngloGold are visible (tab. 4 and fig. 6). Most of the populations are subsistent farmers. This explains why the agricultural lands are in clusters, where they appear as a big mass, they are subdivided into small farms.

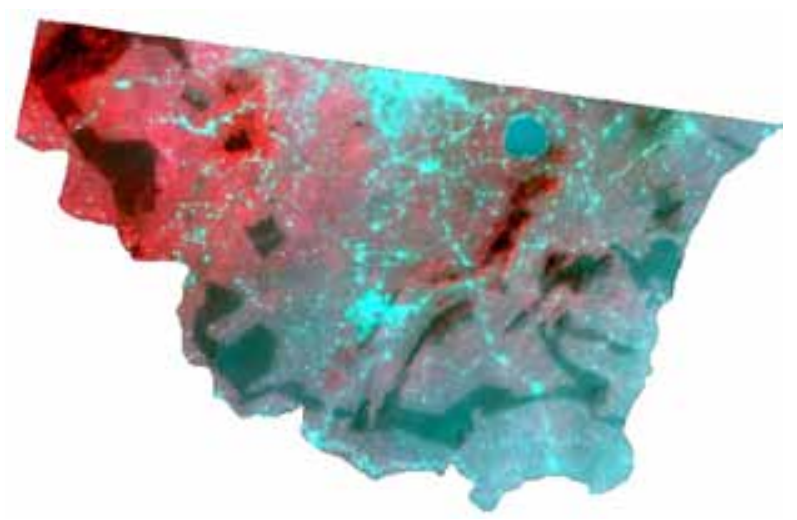

Figure 5. Extracted AOI from 2010 epoch DMC

The land use/cover map for 2000 (fig. 7) Built-up (Settlements) areas increased about 300\% from it 1990 epoch share of LU. Built up now constitute more than $10 \%$ of the LU. Forest has reduced drastically by almost $50 \%$ of its 1990 epoch LU share. Agricultural lands continued its dominations but $60 \%$ of the LU. Water decreased by $10 \%$ less of its 1990 LU share still under $1 \%$ of the LU.

The land use/cover map for 2010 (fig. 8) Built-up (Settlements) area have now taken a quarter of the LU, signally an increase in housing and other allied human utilities. Built up now constitute more than 25 of the LU. Forest loss continues unabated, its has reduced

Table 4. Land use/cover (Ha) Ashanti Region

\begin{tabular}{|l|c|c|c|c|c|c|}
\hline \multirow{2}{*}{ LU } & \multicolumn{2}{|c|}{1990} & \multicolumn{2}{c|}{2000} & \multicolumn{2}{c|}{2010} \\
\cline { 2 - 7 } & Area (ha) & Area (\%) & Area (ha) & Area (\%) & Area (ha) & Area (\%) \\
\hline Forest & $373,900.68$ & 46.06 & $188,898.57$ & 23.27 & $149,040.34$ & 18.36 \\
\hline Agriculture & $398,418.57$ & 49.08 & $510,198.30$ & 62.85 & $452,160.43$ & 55.70 \\
\hline Built-Ups & $33,799.50$ & 4.16 & $107,785.08$ & 13.28 & $205,624.06$ & 25.33 \\
\hline Water & $5,647.68$ & 0.70 & $4,884.48$ & 0.60 & $4,941.61$ & 0.61 \\
\hline TOTAL & $811,766.43$ & 100.00 & $811,766.43$ & 100.00 & $811,766.43$ & 100.00 \\
\hline
\end{tabular}




\section{DE GRUYTER \\ OPEN}

102

from almost $50 \%$ in 1990 epoch LU to less than $20 \%$. Agricultures loses out about 10\% from its share in the 2000 epoch LU. Yet Agriculture remains the dominant LU. Water share remains steady but still under $1 \%$ of the LU.

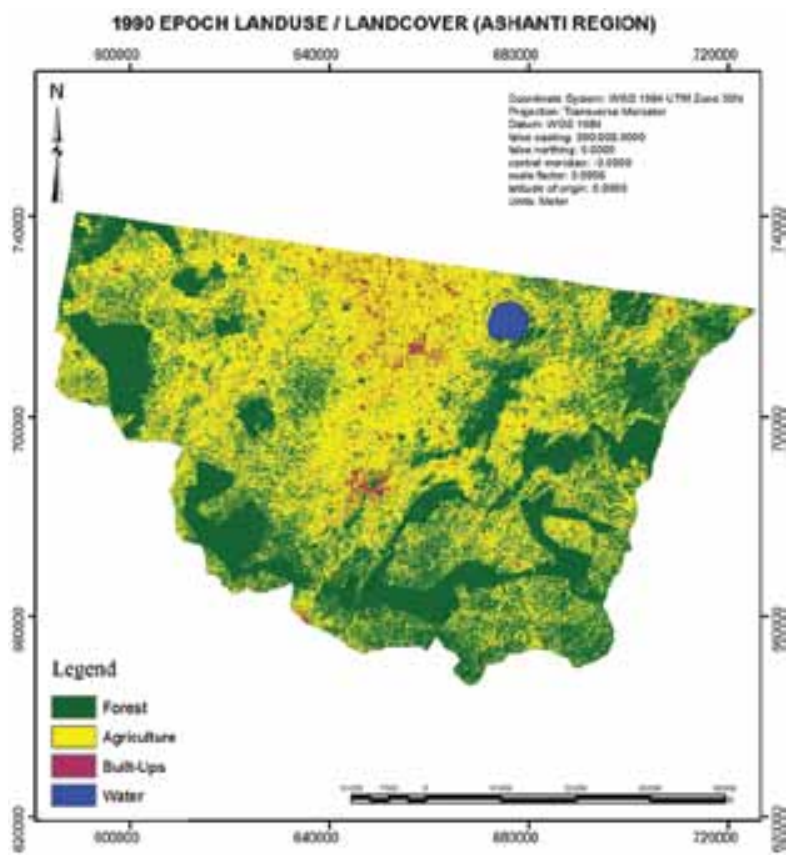

Figure 6. 1990 Epoch land use/cover map

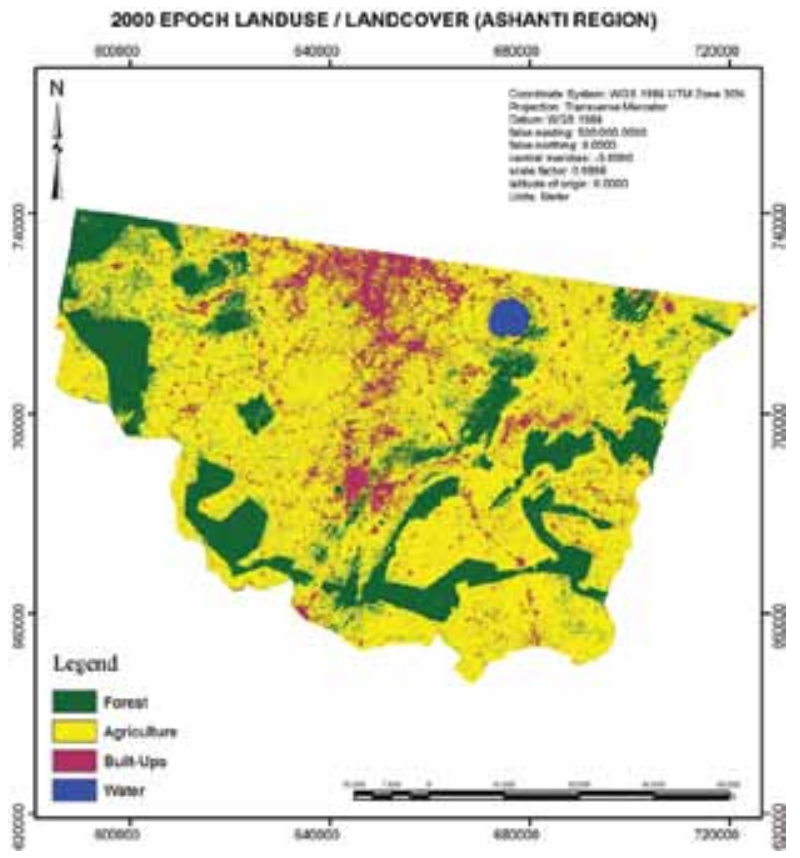

Figure 7. 2000 Epoch land use/cover map

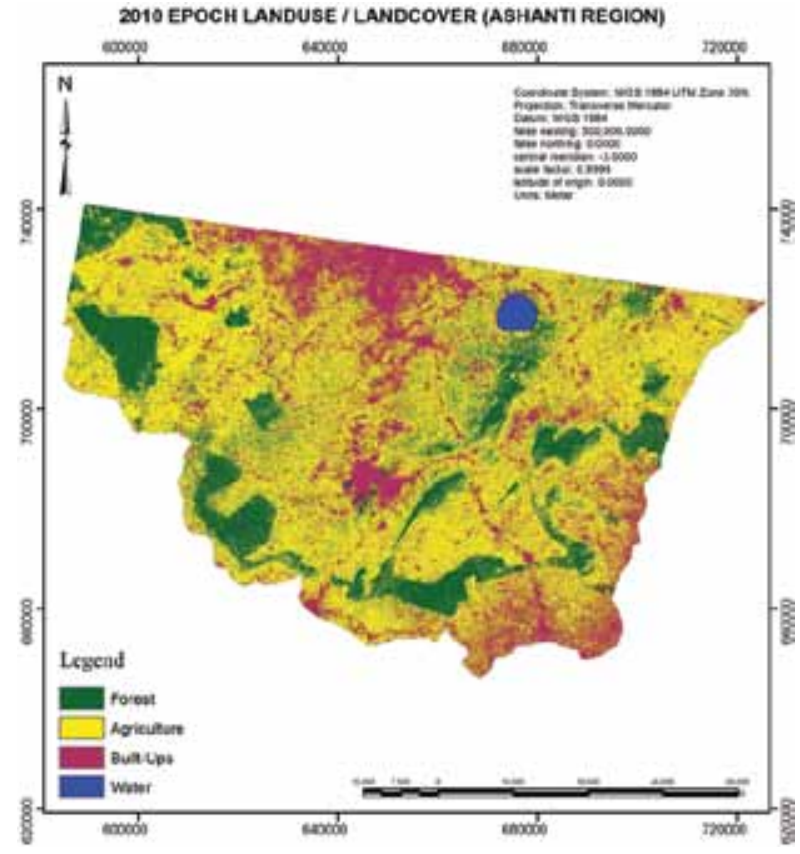

Figure 8. 2010 Epoch land use/cover map

Accuracy assessment of the Land use/cover map produced from the $2010 \mathrm{DMC}, 2000 \mathrm{ETM}+$ and 1990TM were performed. An assessment report was generated in an error matrix, and a Kappa statistics. Overall classification accuracy $85.00 \%$ was obtained. Overall Kappa statistics of 0.7556 was realized. The Forest Preservation Program - Ghana (FPP-Ghana) Ground truthing and verification data was used for this activity. Accuracy assessments for 1990 epoch TM and the 2000 ETM+ images were undertaken through Topographical Map, Aerial Photograph, Land Cover Map, Digitised Topographical data photographs, data and reference points from statutory bodies such as the Forestry Commission and Survey Department. Accuracy results of $80.00 \%$; 0.7111 (1990 epoch TM) and 79.50\%; 0.7067 (2000 epoch ETM+) for Classification accuracy and Kappa Statistic respectively were obtained.

The table 5 shows the extent change of the area of the individual land cover categories in hectares (ha) and the percentage they occupied for 1990-2000 and 2000-2010.

Figure 9 shows the extensive changes that have occurred on almost $35 \%$ of analysed area $(87,402.22$ ha from the total AOI of 811,766.43 ha) between 1990 and 2000. The biggest change was recorded as forested land gave way to agriculture at $24.09 \%$. Forest lost out 
Table 5. Change trajectory $1990-2000$ and 2000-2010 of Ashanti Region

\begin{tabular}{|l|c|c|c|c|}
\hline \multirow{2}{*}{$\begin{array}{c}\text { Land use } \\
\text { trajectory }\end{array}$} & \multicolumn{2}{|c|}{$1990-2000$} & \multicolumn{2}{c|}{$2000-2010$} \\
\cline { 2 - 5 } & $\begin{array}{c}\text { Area } \\
\text { (ha) }\end{array}$ & $\begin{array}{c}\text { Area } \\
\text { (\%) }\end{array}$ & $\begin{array}{c}\text { Area } \\
\text { (ha) }\end{array}$ & $\begin{array}{c}\text { Area } \\
\text { (\%) }\end{array}$ \\
\hline $\begin{array}{l}\text { Forest } \\
\text { - Agriculture }\end{array}$ & $195,570.00$ & 24.09 & $71,004.69$ & 8.75 \\
\hline $\begin{array}{l}\text { Forest } \\
\text { - Built-Ups }\end{array}$ & $8,021.52$ & 0.99 & $6,422.40$ & 0.79 \\
\hline $\begin{array}{l}\text { Agriculture } \\
\text { - Forest }\end{array}$ & $17,852.31$ & 2.20 & $37,484.82$ & 4.62 \\
\hline $\begin{array}{l}\text { Agriculture } \\
\text { - Built-Ups }\end{array}$ & $65,958.39$ & 8.13 & $93,310.02$ & 11.49 \\
\hline Total change & $87,402.22$ & 35.40 & $208,221.93$ & 25.65 \\
\hline
\end{tabular}

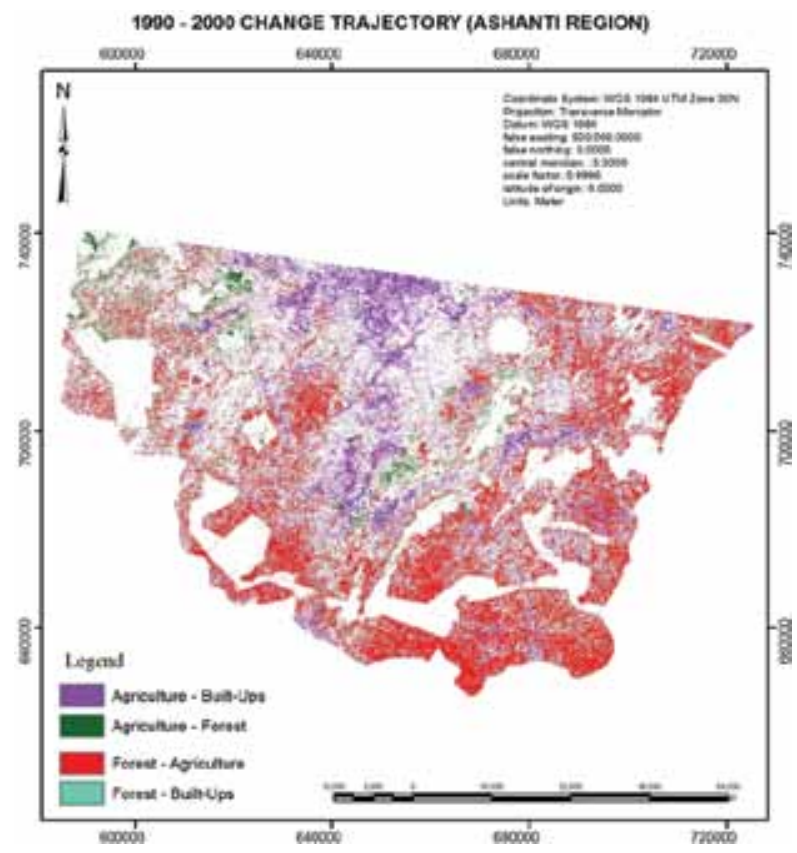

Figure 9. Change trajectory 1990-2000

to Build-Ups at almost $1 \%$, while Forest marginally increased its' share at the expense of Agriculture at $2.20 \%$. Agriculture gave way to Settlement at $8.13 \%$.

Figure 10 displays the changes that have transpired on almost $26 \%$ of analysed area $(208,221.93$ ha from the total AOI of $811,766.43 \mathrm{ha}$ ) between 2000 and 2010. The biggest change was recorded as Agricultural land gave way to Built-up areas at $11.49 \%$. Forest loss to Agriculture was about $5 \%$. Forest lost out marginally to Settle- ment at $0.79 \%$, while Forest increased its share at the expense of Agriculture at almost 5\%. Some $1.43 \%$ of settlement had been converted into Forest.

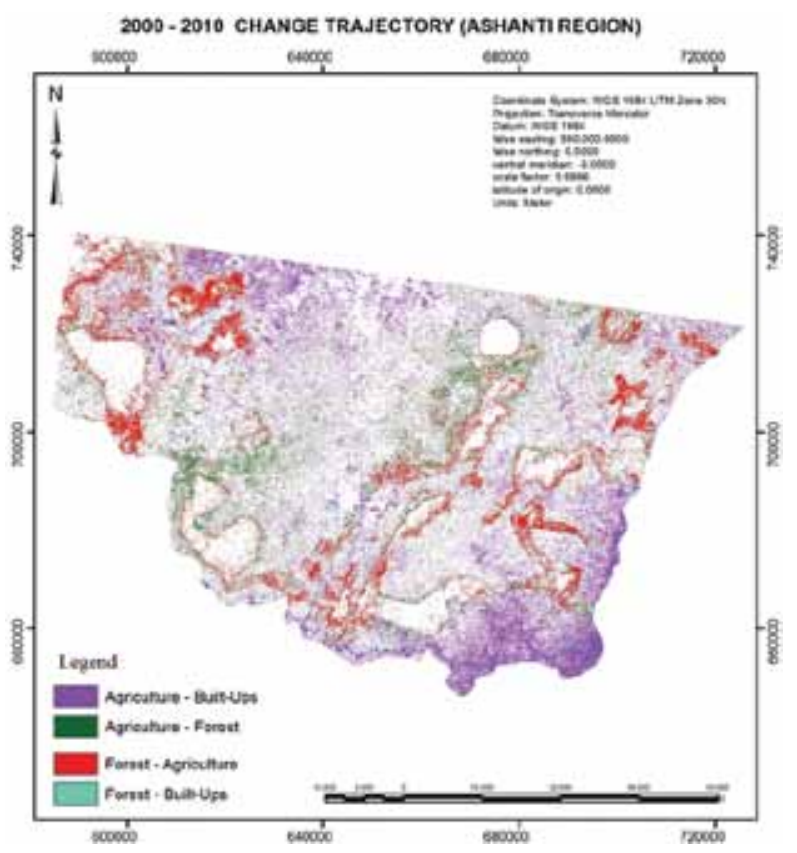

Figure 10. Change trajectory 2000-2010

The LCM model in Idrisi produced from 1990-2000 and 2000-2010 change trajectory maps are shown in figures 11 and 12 measured in hectares. The figures expose the degree of changes (Gains + and Losses) in the study area resulting from the land cover conversions. It can be deduced that with the exception of water all other land cover classes experienced some form of transition either gain or loss. Forests lost out heavily mostly to Agriculture and Built-Ups gained from Agriculture mostly and from Forests. These revealed that, forest loss was extensive.

\section{Prognosis of forest loss}

Markov Chain Analysis and Cellular Automata were used to predict the future land cover map of 2010 using the land cover maps of the years 1990-2000 in the Ashanti Region (AOI-1). This predicted map was subsequently compared with the actual land cover map of 2010 for validation (fig. 13). Validation is considered to play a vital role in the modeling process (Pontius 2010). A validation process was performed to explain how well the predicted map resembles the reference map. 


\section{DE GRUYTER \\ OPEN}
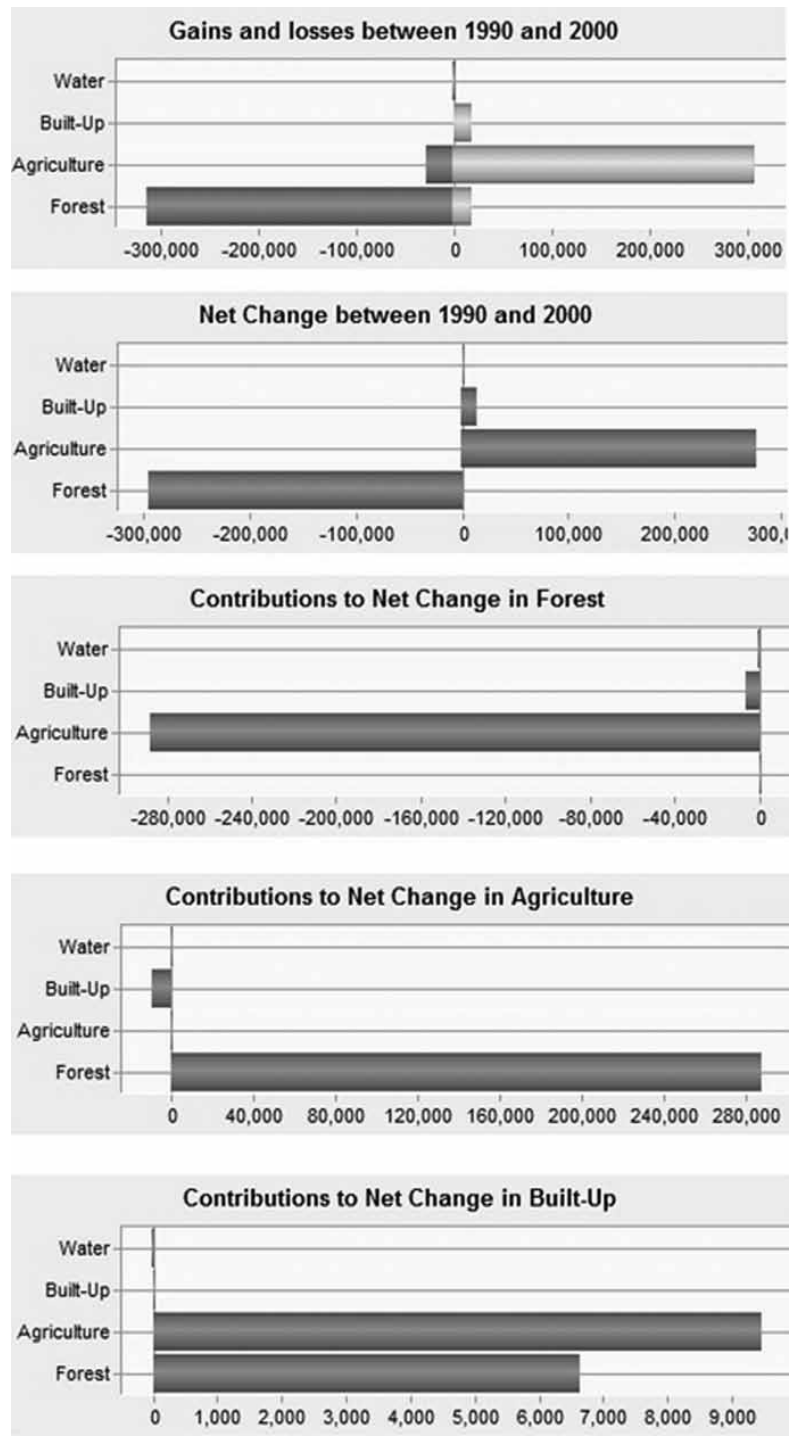

Figure 11. Trend analysis 1990-2000

The validation employed kappa statistic generated from VALIDATE module in Idrisi. The $\mathrm{K}_{\mathrm{no}}$ indicates the overall accuracy of prediction. This was calculated to be $82 \%$. Other kappa statistics like $\mathrm{K}_{\text {location }}$ and $\mathrm{K}_{\text {qual- }}$ ity were computed to be $82 \%$ each. These values are found to fall within the standard values suggested by Monserud and Leamans (1992) that a value of kappa of $75 \%$ or greater show a very good to excellent classifier performance, while a value less than $40 \%$ is poor.

The land use/cover map for 2020 and 2030 was projected using the 2000 and 2010 land use/cover maps in the same way juxtaposing that the transmission mechanisms stay the same.
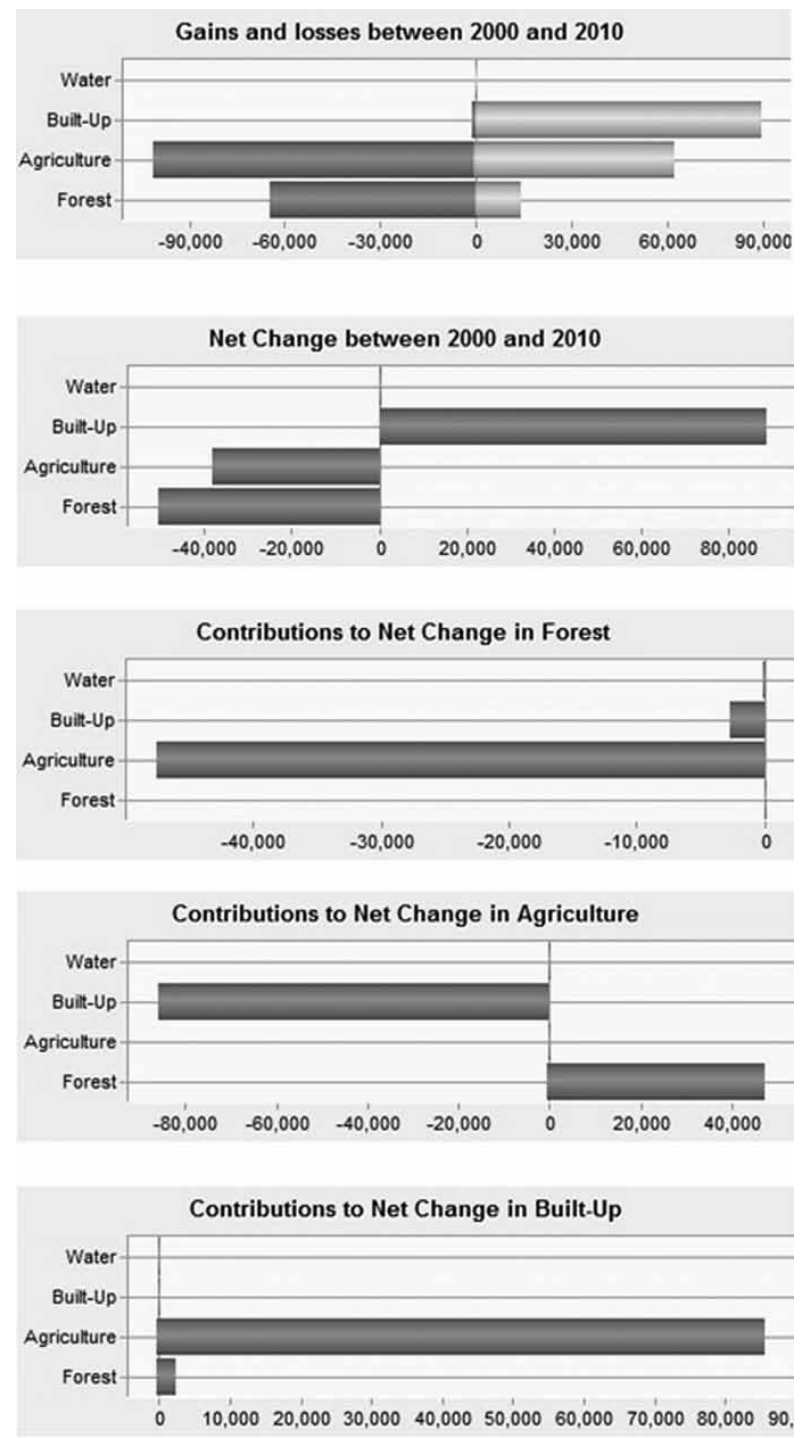

Figure 12. Trend analysis 2000-2010

Although there is no concrete conclusion on the criteria to assess the performance of land cover change models, validation is considered to play a vital role in the modelling process (Pontius 2000). A validation process was performed to explain how well the predicted map resembles the reference map.

Figure 14 shows the predicted 2020 land use/cover map. Forest cover had whittled to a mere $10 \%$. Agriculture continues to dominate at the expense forest cover of the Ashanti Region. Built-Up category is the highest gainer and this is mostly at the expense of Agriculture. Water level remains stable. Prognosis for Ashanti is not optimistic at all for forest land use/cover. 


\section{DE GRUYTER \\ OPEN}

$j^{N}$

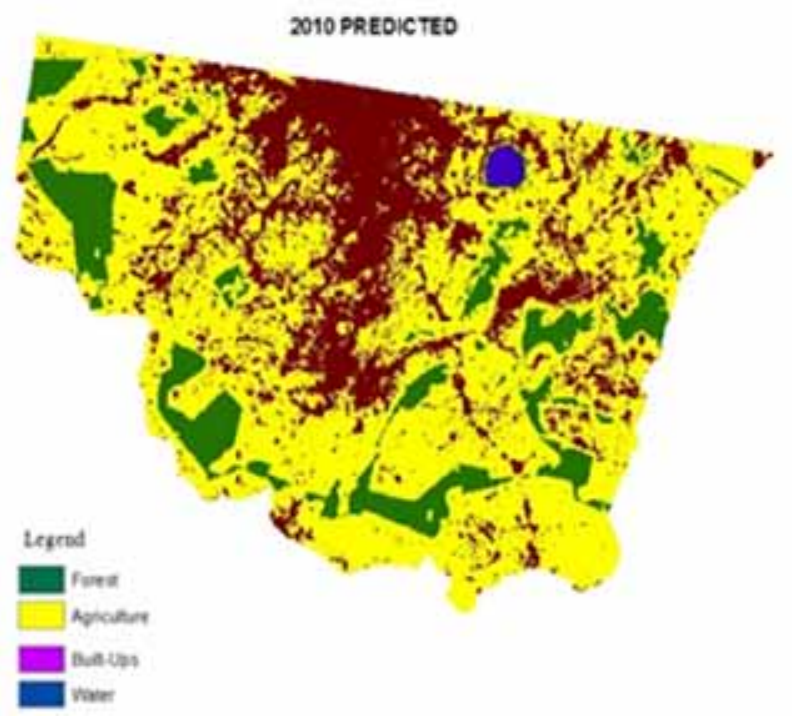

Figure 13. 2010 Validation (actual and predicted)

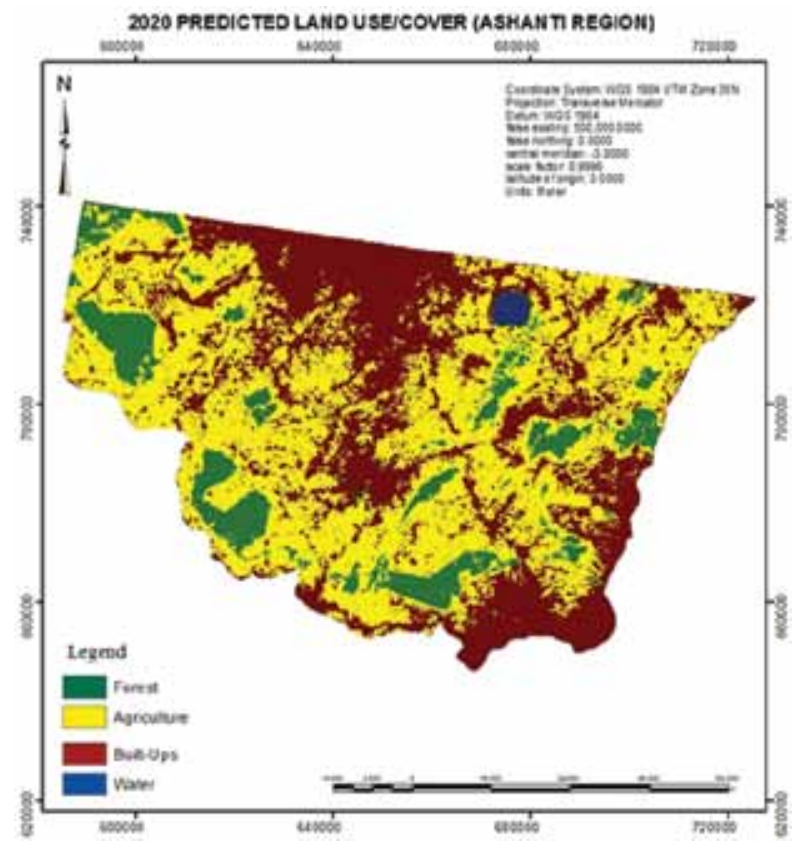

Figure 14. 2020 Predicted land use/cover

Figure 15 displays the predicted 2030 land use/cover map. Forest cover had been reduced to a measly $9 \%$. Agriculture remains the dominant land use class at the

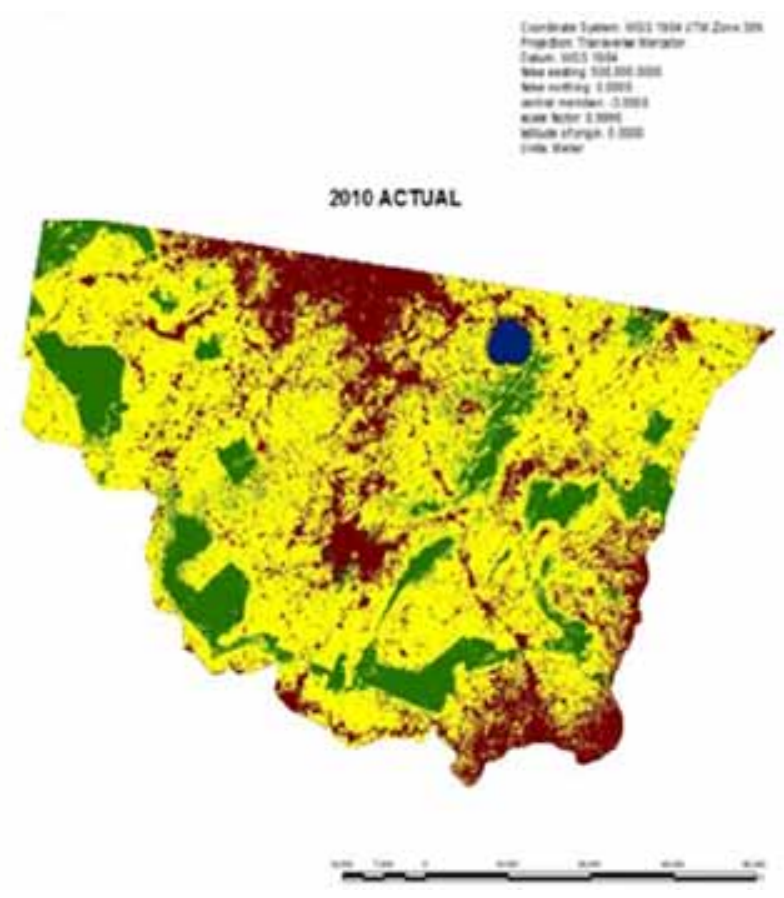

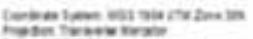

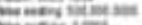
inowine

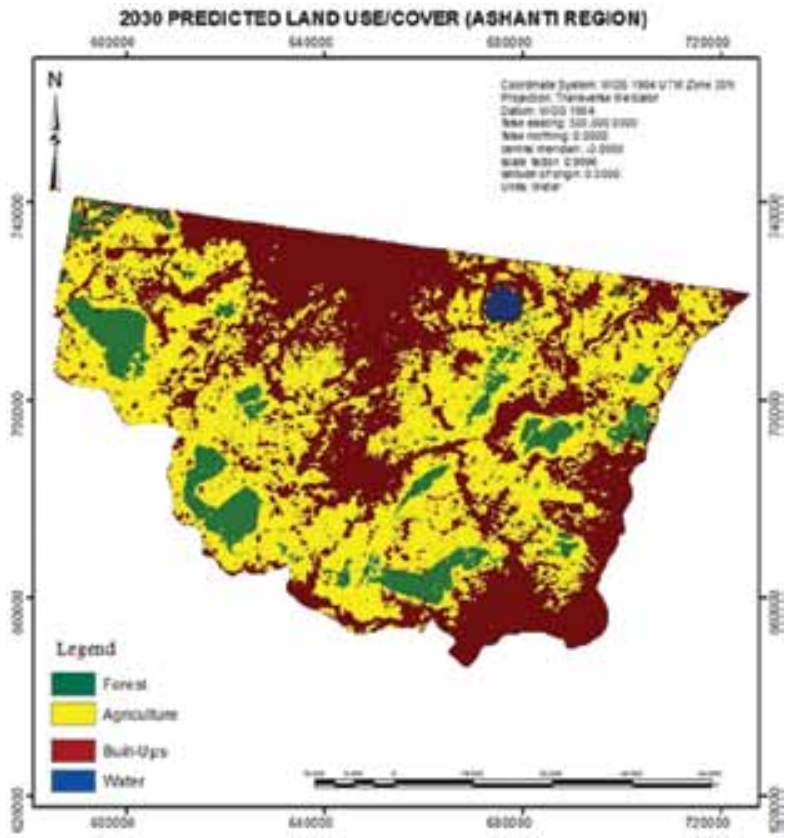

Figure 15. 2030 Predicted land use/cover

expense forest cover. Built-Up category is the highest gainer and this is mostly at the expense of Agriculture and now almost at par with Agriculture. Water level re- 


\section{DE GRUYTER \\ OPEN}

mains stable. Prognosis for Ashanti is not positive at all for forest cover.

The table 6 displays the predicted extent of the area of the individual land cover categories in hectares (ha) and the percentage they occupied and figure 16 indicates the graph depicting the trends of land cover changes in the years 2020 and 2030 .

Table 6. Predicted land use/cover for 2020 and 2030 in the Ashanti Region

\begin{tabular}{|l|r|r|r|r|}
\hline \multirow{2}{*}{ LU } & \multicolumn{2}{|c|}{2020} & \multicolumn{2}{c|}{2030} \\
\cline { 2 - 5 } & Area (ha) & $\begin{array}{c}\text { Area } \\
(\%)\end{array}$ & Area (ha) & $\begin{array}{c}\text { Area } \\
(\%)\end{array}$ \\
\hline Forest & $86,961.96$ & 10.72 & $72,930.06$ & 8.99 \\
\hline Agriculture & $417,313.17$ & 51.44 & $383,167.44$ & 47.23 \\
\hline Built-Up & $302,795.55$ & 37.32 & $350,977.68$ & 43.26 \\
\hline Water & $4,235.13$ & 0.52 & $4,230.63$ & 0.52 \\
\hline TOTAL & $811,305.81$ & 100.00 & $811,305.81$ & 100.00 \\
\hline
\end{tabular}

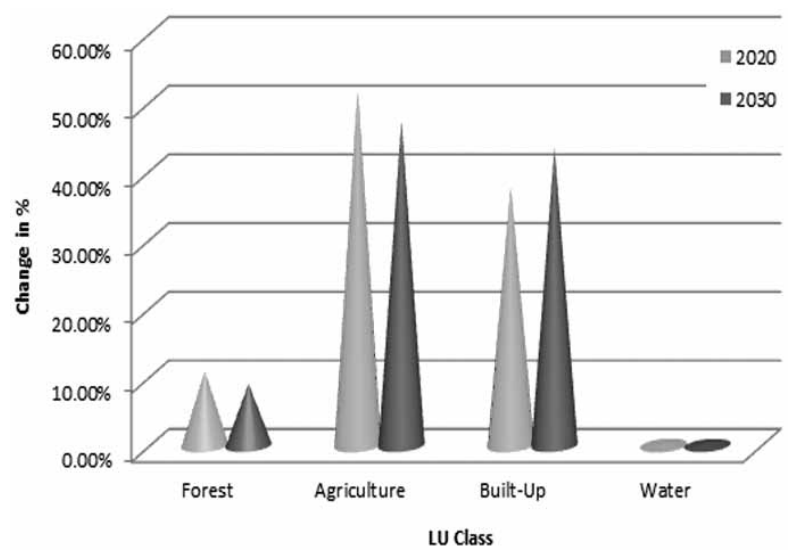

Figure 16. 2020-2030 predicted land use/cover

Figure 17 displays the trend of land use/cover from 1990-2030 spanning forty years. The graph indicates a very grim future for forest. Forest loss is huge; from as high $50 \%$ in 1990 by 2030 , it is under $9 \%$. Agriculture remains steadily high, and retains its position as the dominant land use/cover type. Built-ups category is the fastest growing land use class from under 5\% in 1990, but by 2030 it had reached $43 \%$. The water category remains stable.

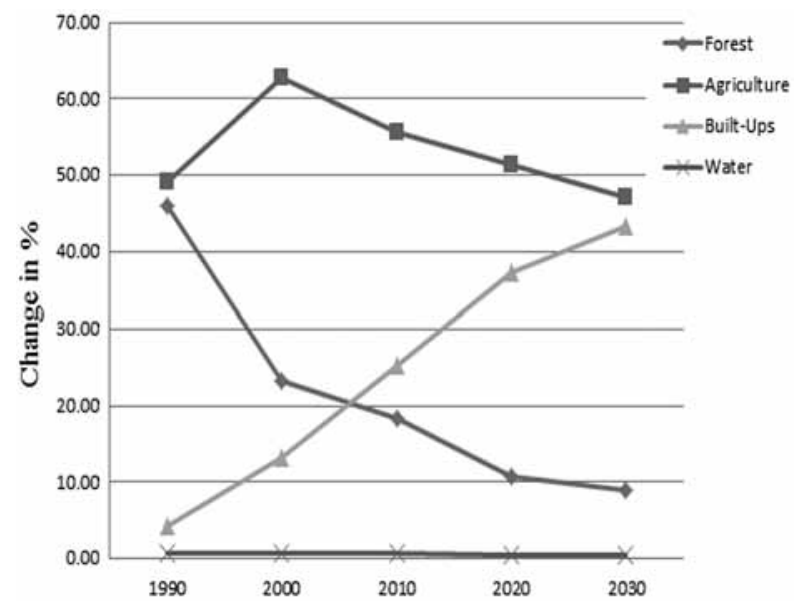

Figure 17. Land use/cover trend 1990-2030 (Ashanti)

\section{Discussion}

\section{Land use/cover classification and change analysis}

The results revealed the huge potential of remote sensing for land use/cover studies. The utilization of this method in monitoring the changing pattern of forest cover is very incisive and efficient. Remote sensing offers some of the most precise means of assessing the magnitude and pattern of changes in forest cover over a period of time (Miller et al. 1998). Satellite data provides an important means in forest change detection studies because of the periodic and coverage of the satellites at relatively short intervals (Mas 1999).

Using remote sensing data for forestry studies over large area is very efficient, less time consuming and comparatively cheaper as compared to other methods of forest inventory methods. But the cost of getting the requisite satellite data for such studies is a big challenge for researches in Africa as the cost of satellite images is high. Governments of Sub Saharan African countries have not invested in satellite technology. Researchers in Africa thus mostly rely on Landsat images (which are free) and donor funded studies such as the Forest Preservation Program - Ghana (FPP-Ghana) which is funded by the Government of Japan to provide data and other resources to fund remote sensing studies. These projects/programs come with their specified satellites images which might not necessarily address some of the concerns of the benefitting country. 
Supervised classification was employed to classify the individual images into the different land cover classes. Stratified random sampling was used in the selection of the training sites for the supervised classification. Stratified random sampling is using expert knowledge, the field area is distributed into strata that maximize the differences between units, and minimize the variation within each unit. One or more strata selected are estimated to be main drivers of the system under observation. A random sample is then drawn from each stratum or unit. When known differences exist between the strata, stratified random sampling with balanced allocation can every now and then provide improved estimation without adding bias (Snedecor and Cochran 1989). The biggest merit using stratified random sampling is that, it produces results that are both largely unbiased and accurate. Stratified often produces data that is more representative of the entire population because of the special attention it pays to the smaller subgroups within the population. It is also the best way to obtain results that reflect the diversity of the population in question. This advantage makes stratified sampling much more effective than simple sampling for large and diverse populations as the terrain in portrayed.

The overall accuracy obtained for land use cover maps 2010, 2000 and 1990 were 85\%, 80\% and 79.50\% respectively for AOI-1(Ashanti Region). The statistics was very satisfactory and the accuracy very high for a terrain that, had many mosaic agricultural land ranging from tree crops such as cocoa, cashew, citrus, Palm; shrubs and herbaceous plants. Stratified random samplings employed ensured that, all the mosaic substrata were all duly represented and classified accordingly.

The overall kappa statistics obtained for 2010, 2000 and 1990 land cover maps for ranged between 0.651 and 0.755 respectively. So the results obtained in the described analysis are of strong to moderate agreement what allows for performing further analysis and formulating valid conclusions.

The land use/cover classification for the study is very consistence with studies conducted by other researches such as (Hansen et al. 2013; Kim et al. 2014; Sexton et al. 2013; Townshend et al. 2012).

The land use/cover for 1990, 2000 and 2010 showed forest loss increasing from year to year. Forest loss through deforestation is observed mostly outside of the designated national forest reserve or protected area. The forests outside the forest protected areas had been converted into agricultural land. Degradation of the forests is observed in the protected areas as logging, farming encroachment and illegal mining is seen in the protected areas.

\section{Land cover change analysis}

Change Detection studies have several implications depending on the scope and interest of the user (Singh 1989; Lu et al. 2004; Petit et al. 2001); yet, the most wide spread understanding of the Change Detection application is its capability to deliver data on changes with regards extent, trend, location and how the change has spatially been distributed.

From 1990 to $2000,35 \%$ and $26 \%$ for $2000-2010$ respectively of the Ashanti Region landscape had undergone profound changes which are attributable to anthropogenic activities. The Change maps (fig. 11-12) show the distribution of exchanges in the land use cover classes revealing the location of changes in the AOI. It can be inferred from the figures that changes occurred all over the study area with most of the changes occurring close to built-up areas indicating the influences of human activities on the land cover and increased agricultural activities. Forests which used to be the dominant land use/cover class have now been lost to Agriculture. Built-up class has gained so much from Agriculture.

Deforestation is observed outside the protected area, while degradation is witnessed in the many protected areas in the AOIs.

\section{Prognosis for the years 2020 and 2030}

Markov-Cellular Automaton model was used in this study was found to be acceptable. The predicted 2010 map produced from 1990 and 2000 LULC maps was compared with the actual 2010 LULC map. The Kappa value of $82 \%$ was attained in accuracy assessment. According to Monserud and Leamans (1992) this results indicated an excellent model with excellent prediction.

However, there were some observed discrepancies in the spatial distribution of the Built-ups class. Builtup class had been over concentrated at the top of the predicted image when compared to the original image. The predicted 2010 map though statistically deemed to be very good, when compared to the actual 2010 LULC map of the same area. The distribution of the Built-up 


\section{DE GRUYTER \\ OPEN}

class was over concentrated in the top of the image. Built-up class in the lower part of the image had been filtered off. These observed discrepancies could be ascribed to the contiguity filter applied in the modeling process. The utilization of adequate suitable maps signifying the driving factors data on the degree of impact on the land cover types in upcoming modeling reduces the risk of discrepancies (Clarke et al. 1997; Zamyantin and Markov 2005). Population data, meteorological data and policy data were excluded in the modeling.

Figures $16-17$ and table 6 indicate a very grim forecast for forest for the years 2020 and 2030. It is obvious that all the land use/cover classes except forests and water would be increasing. Agriculture stagnated and experienced a marginal loses to Built-ups. Built-up class surge continues as the years go by. This is attributed to the population growth rate of Ghana (GSS 2013). But for the statutory and protected forest reserves, no forest would be found in the year 2020 and beyond. Forest cover will be around $11 \%$ in 2020 and drop to $9 \%$ in 2030.

\section{Conclusions}

This study utilized the integration of Remote Sensing, GIS and Stochastic Modeling techniques to analyze and quantify the land cover changes (amount, trend and location) that have occurred within the period of 1990 and 2010 in the Ashanti Region. There are ample proofs from the results that, the study area had undergone extensive land cover changes.

The creation of land use/cover map for the study areas was derived utilizing standardized digital remote sensing classification techniques. A hierarchical level I land use and land cover classification comprised of Forest, Agriculture, Water and Built-ups. The final classification accuracy was determined to be satisfactory or 'good' by means of employing standardized accuracy assessment measures.

The remote sensing based mapping is characterized by, but not restricted to, inherent limitations. No map produced by digital manipulation of multispectral data is ever $100 \%$ correct when it is produced by a computer (Robinove 1986). By nature, the process of classifying such a broad range of the Earth's features into specific and often simplified classes introduces error by drawing boundaries around geographically located classes that are 'homogeneous' or acceptably heterogeneous. However, these limitations can often be overcome by sound statistical analysis to produce acceptably accurate land use and land cover maps as derived from satellite data as was employed in this study.

The application of Landsat multi-temporal images and DMC to identify land cover types in the study area was done successfully and proved inexpensive to detect land cover changes at such a large-scale level.

The Markov Chain analysis and Cellular Automaton were utilized to predict a likely land use/cover map of the years 2020, 2030. The predictions shown a continuous increased of built-ups, Agriculture at the expense of forests. While the use of Markov Chain analysis and Cellular Automaton was successful, it is significant to iterate the following limitations of the model:

1. It is computationally exhaustive.

2. Predictions were solely based on past history of classified LULC map but did not to take into account the future trends and other causal factors which might not be present in the landscape in the past.

3. The predictions show some glitches in the land cover conversions spatially.

In spite of these limitations, the forecast maps created in this dissertation can be employed by decisionmakers in government and private sector to analyze and evaluate policies to restrain wanton destruction of the forest lands and unbridled housing and economic development policies. Again for REDD+ purposes, it provides a vital link for MRV activities.

The study used ERDAS Imagine, Idrisi, ArcGIS software. The multiple use of three different software indicates that, each of these software is limited at certain process. Ability to use multiple remote sensing and GIS is necessary for researchers in LULC studies.

\section{Limitations}

Two limitations were identified in this study

1. Challenges with satellite data availability for the exact years impacted the study. More cloud free satellite images for the areas of study would have been much better.

2. The modeling process was performed based on a model which have inbuilt limitation which affected it predictions. 


\section{Recommendations}

The following recommendations are necessary for the future.

1. Additional studies must be undertaken to compare the validation of predicting land cover map where the time period between the future date and later date much shorter.

2. This study was based on first order Markov process for predicting the future land use/cover changes and considering the limitations mentioned in section 6.1ii, further work should explore other advanced modeling approaches for forecasting land cover changes.

3. The twenty-year time span, 1990-2010, considered in this study is relatively a short increment of time in a long history of land use dynamics, but even then the changes were profound. This means that changes in the tropics are much faster than other parts of the world.

To have forests in the foreseeable future in the Ashanti Region, major intervention and deliberate steps must be taken place to salvage what is left of our forests, because the forecast is very grim. All efforts must be spent at salvaging what is left of our forest. This clarion call, the Chinese puts it succinctly, "The best time to plant a tree was 20 years ago. The second best time is now".

\section{References}

Abay T. 2014. Factors Affecting Forest User's Participation in Participatory Forest Management; Evidence from Alamata Community Forest, Tigray; Ethiopia. Retrieved from http:/opendocs.ids.ac.uk/opendocs/ handle/123456789/4227.

Agbosu L.K. 1983. The Origins of Forest Law and Policy in Ghana during the Colonial Period. Journal of African Law, 27, 2, 169-187. Retrieved from http://journals.cambridge.org/abstract_S0021855300013218.

Aragão L.E.O.C., Poulter B., Barlow J.B., Anderson L.O., Malhi Y., Saatchi S., Gloor E. 2014. Environmental change and the carbon balance of Amazonian forests. Biological Reviews, 89 (4), 913-931. doi:10.1111/brv.12088.

Bele M.Y., Sonwa D.J., Tiani A.M. 2015. Adapting the Congo Basin forests management to climate change: Linkages among biodiversity, forest loss, and human well-being. Forest Policy and Economics, 50, 1-10. doi:10.1016/j.forpol.2014.05.010.

Benneh G., Agyepong G.T. 1990. Land Degradation in Ghana, London: Commonwealth Secretariat/University of Ghana.

Boafo J. 2013. The Impact of Deforestation on Forest Livelihoods in Ghana, Africa Portal. Retrieved September 12, 2014, from http://www.africaportal.org/articles/2013/01/16/impact-deforestationforest-livelihoods-ghana\#chapter\%3C?php print \$chapter;?\%3E.

Clarke K.C., Hoppen S., Gaydos L. 1997. A self-modifying cellular automaton model of historical urbanization in the San Francisco Bay area. Environment and Planning B: Planning and Design, 24, 247-261.

Dei G.J.S. 1992. A forest beyond the trees: Tree cutting in rural Ghana. Human Ecology, 20 (1), 57-88. doi:10.1007/BF00889696.

EPA-Environmental Protection Agency. 2004. Ghana State of the Environment Report, EPA Ghana, Accra, $11-51$.

GSS. 2013. 2010 Population and Housing census National analytical report. Accra, Ghana, 1-430.

Hansen M.C., Potapov P.V., Moore R. 2013. High-resolution global maps of 21st-century forest cover change. Science, 342, 850-853.

Huang J., Wu Y., Gao T., Zhan Y., Cui W. 2015. An integrated approach based on Markov Chain and cellular automata to simulation of urban land use changes. Applied Mathematics and Information Sciences, 9 (2), 769-775.

IIED - International Institute for Environment and Development. 1987. Our common Future: A readers Guide, London: Earthscan.

Jabbour J., Hunsberger C. 2014. Visualizing relationships between drivers of nvironmental echange and pressures on land-based ecosystems. Natural Resources, 5 (04), 146-160. doi:10.4236/nr.2014.54015

Jones W.B., Bacon M., Hastings D.A. 1981. The Lake Bosumtwi impact crater, Ghana. Geological Society of America Bulletin, 92 (6), 342-349. doi:10.1130/0016-7606(1981)92.

Kalema V.N., Witkowski E.T.F., Erasmus B.F.N., Mwavu E.N. 2014. The impacts of changes in land use on woodlands in an equatorial African savanna. Land Degradation and Development. doi:10.1002/ ldr.2279. 


\section{DE GRUYTER

Kim D.H., Sexton J.O., Noojipady P., Huang C., Anand A., Channan S., Townshend J.R. 2014. Global, Landsat-based forest-cover change from 1990 to 2000. Remote Sensing of Environment, 155, 178-193. doi:10.1016/j.rse.2014.08.017.

Kissinger G., Herold M. 2014. Drivers of deforestation and forest degradation: a synthesis report for REDD+ policymakers. Retrieved from http://www. fao.org/nr/lada/index.php?option=com_content\&vi ew $=$ article \&id $=186$ : deforestation\&catid $=1 \&$ Itemid $=171 \&$ lang $=$ en.

Lillesand T. Kiefer R.W. 2008. Remote sensing and image interpretation (6th Edition). JohnWiley and Sons Inc., New York.

Lu D., Mausel P., Brondizio E., Moran E. 2004. Change detection techniques. International Journal of Remote Sensing, 25 (12), 2365-2407.

Mas J.F. 1999. Monitoring land-cover changes: A comparison of change detection techniques. International Journal of Remote Sensing, 20 (1), 139-152. doi:10.1080/014311699213659.

Medrilzam M., Dargusch P., Herbohn J., Smith C. 2013. The socio-ecological drivers of forest degradation in part of the tropical peatlands of Central Kalimantan, Indonesia. Forestry, 87 (2), 335-345. doi:10.1093/forestry/cpt033.

Michetti M., Zampieri M. 2014. Climate-human-land interactions: A review of major modelling approaches. Land, 3 (3), 793-833. doi:10.3390/land3030793.

Miller J.H. 1998. Active nonlinear tests (ANTs) of complex simulation models. Management Science, 44 (6), 820-830.

Mishra V.N., Rai P.K., Mohan K. 2014. Prediction of land use changes based on land change modeler (LCM) using remote sensing: A case study of Muzaffarpur (Bihar), India. Journal of the Geographical Institute Jovan Cvijic, SASA, 64 (1), 111-127. Retrieved from http://www.doiserbia.nb.rs/Article. aspx?id=0350-75991401111M\&AspxAutoDetectCo okieSupport=1\#.VMjUjmKsVjo.

Monserud R.A., Leamans R. 1992. Comparing global vegetation maps with the kappa statistic. Ecological Modelling, 62, 275-293.

Monson R.K. 2013. Ecology and the Environment. Springer, New York. doi:10.1007/978-1-4614-7612-2

Petit C., Scudder T., Lambin E. 2001. Quantifying processes of land cover by remote sensing: resettle- ment and rapid land cover changes in south-eastern Zambia. International Journal of Remote Sensing, 22 (17), 3435-3456.

Pontius G.R. 2000. Quantification error versus location error in comparison of categorical maps. Photogrammetry Engineering of Remote Sensing, 66, 1011-1016.

Razavi B.S. 2014. Predicting the trend of land use changes using artificial neural network and Markov Chain Model ( Case Study: Kermanshah City). Research Journal of Environmental and Earth Sciences, 6 (4), 215-226.

Robinove C.J. 1986. Principles of logic and the use of digital Geographic Information Systems. U.S. Geological Survey Professional Paper No. 977. U.S. Gov. Printing Office, Washington, D.C.

Ronneberg K., Tol R.S.J., Schneider U.A. 2005. KLUM: A simple model of global agricultural land se as a ucoupling tool of economy and vegetation; FNU Working Paper No. 65; Hamburg University and Centre for Marine and Atmospheric Science: Hamburg, Germany.

Rounsevell M.D.A., Annetts J.E., Audsley E., Mayr T., Reginster I. 2003. Modelling the spatial distribution of agricultural land use at the regional scale. Agriculture, Ecosystems and Environment, 95, 465-479.

Schelhaas M.J., Eggers J., Lindner M., Nabuurs G.J., Pussinen A., Päivinen R., Schuck A., Verkerk P.J., van der Werf D.C., Zudin S. 2007. Model documentation for the European Forest Information Scenario Model (EFISCEN 3.1.3); EFI Technical Report 26; Alterra: Wageningen, The Netherlands.

Sexton J., Huang C., Channan S., Feng M., Song X., Kim D., Townshend J.R. 2013. Global, long-term Earth Science Data Records of forest cover, change, and fragmentation from Landsat: the Global Forest Cover Change Project. AGU Fall Meeting Abstracts, -1, 0432. Retrieved from http://adsabs.harvard.edu/abs/2013AGUFM.B41D0432S.

Singh A. 1989. Digital change detection techniques using remotely sensed data. International Journal of Remote Sensing, 10 (6), 989-1003.

Snedecor G.W., Cochran W.G. 1989. Statistical methods, eighth edition. Iowa State University Press.

Stephenne N. Lambin E.F. 2004. Scenarios of land-use change in Sudano-Sahelian countries of Africa to 
better understand driving forces. GeoJournal, 61, 365-379.

Stéphenne N., Lambin E.F. 2001. A dynamic simulation model of land-use changes in Sudano-Sahelian countries of Africa (SALU). Agriculture, Ecosystems and Environment, 85, 145-161.

Townshend J.R., Masek J.G., Huang C., Vermote E.F., Gao F., Channan S., Wolfe R.E. 2012. Global characterization and monitoring of forest cover using Landsat data: opportunities and challenges. International Journal of Digital Earth, 5 (5), 373-397. doi:10.1080/17538947.2012.713190.

Van Delden H., Luja P., Engelen G. 2007. Integration of multi-scale dynamic spatial models of socio-economic and physical processes for river basin management. Environmental Modelling and Software, 22, 223-238.

Veldkamp A., Fresco L.O. 1996. CLUE-CR: An integrated multi-scale model to simulate land use change scenarios in Costa Rica. Ecological Modelling, 91, 231-248.

Verburg P. Overmars K. 2009. Combining top-down and bottom-up dynamics in land use modelling: Exploring the future of abandoned farmlands in Europe with Dyna-CLUE model. Landscape Ecology, 24, 1167-1181.

Wright I.A., Smeets P.J.A.M., Elbersen B.S., Roos Klein-Lankhorst, J., Pflimlin A., Louloudis L., Vlahos G., Crabtree J.R., Williams S.M., Hinrichs P., et al. 1999. The ELPEN project. In A Protocol for Building the ELPEN Livestock Policy Decision Support System; Macaulay Land Use Research Institute (MLURI). Aberdeen, UK.

Zamyatin A., Markov N. 2005. Approach to land cover change modelling using the cellular automata // Proceedings of 8 Conference on Geographic Information Science, Estoril, Portugal, AGILE, 587-592. 